\title{
Radio Republik Indonesia Surakarta, 1945-1960s: Its Role in Efforts to Maintain Indonesian Independence and the Formation of National Culture
}

\author{
Dhanang Respati Puguh \\ Department of History, Faculty of Humanities, Diponegoro University
}

*Corresponding Author: dhanang.respati@live.undip.ac.id

\begin{abstract}
This article discusses the role of Radio Republik Indonesia (RRI, The Radio of Republic of Indonesia) Surakarta in the period 1945-1960s. In that period RRI Surakarta had two roles in the context of decolonization. In the period 1945-1949, RRI Surakarta had a role in the effort to maintain the independence of Indonesia. The RRI Surakarta employees struggled

Received:

8 December 2017

Accepted:

18 December 2017 transmitter so that the struggle of the Indonesian nation in defending the independence of Indonesia could be broadcasted to various parts. In the period 1950-1960s RRI Surakarta participated in efforts to formation a national culture. When the discourse of national culture continued to be discussed by the elite of Indonesia, since 1950 the Bureau of the Radio of Republic of Indonesia had set the establishment and the choice of ways to build a national culture. In this connection, RRI should be directed to build a national culture. Based on the policy of the Bureau of Radio of Republic of Indonesia, RRI Surakarta realized that idea by organizing Javanese art broadcasts (gamelan, wayang wong, kethoprak, and shadow puppets), "local entertainment" and national music, and organizing Radio Star Competition. RRI Surakarta Radio Star made an important role in the creation of popular music in Indonesia.
\end{abstract}

Keywords: Radio of Republic of Indonesia; Javanese Art Broadcast; 'Local Entertainment'; National Music.

\section{Introduction}

Radio has played an important role in the stage history of Indonesia. Wild (1986) has shown that in the revolution (1945-1950) radio had an influence in the struggle of the Indonesian nation. Meanwhile, Lindsay (2015) says that the role of radio is also important to understand the history of Indonesia during the 1950s-1960s. At that time, the foreign broadcasted to Indonesia, the radio as the most important information channel between the outside world and Indonesia, the national broadcasting radio as a broadcast voice Indonesia region. However, in the study of the history of Indonesia, this somewhat neglected because the difficulty to obtain archival materials. Therefore, the role of radio is one of the open topics for research 
including the national cultural programs of RRI and its branches in the region (Lindsay 2015: 25). Starting from the case, this paper is an early study which attempts to discuss the role of radio by taking the case of RRI Surakarta in1945-1960s period. The discussion is focused on two main issues, namely the role in order to preserve the independence and the formation of a national culture. The discussion begins with a description of the establishment of RRI Surakarta, sequentially followed by the role in the effort to maintain the independence, and formation of a national culture.

\section{The Establishment of RRI Surakarta in 1945}

The firstly introduced in Indonesia in the early 20th century, radio soon gained the wide participation of the people in Indonesia, with the emergence of amateur radio. However, legitimate broadcasting radio in Indonesia began with the Bataviaasche Radio Vereeniging (BRV) in Weltevreden, established on June 16, 1925. BRV was managed by a group of radio enthusiasts who broadcasted music events at the west of a room Hotel des Indes. Financing program originally broadcasted from its audience contribution: in the later development supported by ads. BRV then got a new name Radio Omroep Nederlandsch-Indische Maatschappij (NIROM, Netherlands East Indies Institute of Radio) in 1934, and turned into official government channels. Besides, NIROM had licensing rights to collect money from all the owners of radio, private radio stations could also be found in the media arena during the Dutch colonial Indonesia (Lindsay 1997: 110).

Before NIROM began an official broadcasting, in Surakarta had stood an Eastern radio transmitter, the PK2MN undertaken by the Society of Javaanse Kunstkring Mardi Raras Mangkunagaran receiving support from Mangkunagara VII. In 1927, Mangkunagara VII installed a set of broadcasting receivers to listen directly to the sound of Queen Wilhelmina of the Netherlands. Six years later, exactly on 1 April 1933 with the support of Mangkunagara VII, Ir. Sarsito Mangun Kusumo established a radio station and formed Soloche Radio Vereeniging (SRV). SRV was the first Eastern radio station in Indonesia that made Javanese art become the subject matter of broadcasts. Since Indonesia Muda (Young Indonesian) played a role in organizing broadcasts on SRV, there was a press release Hawaiian, keroncong, radio plays, scouting, sports, and others. SRV broadcasts became more popular among the younger. In addition, in 1934 in Surakarta was also founded Siaran Radio Indonesia (SRI, Indonesian Broadcast Radio) under the tutelage of Prince Suryohamijoyo and Mulyadi Joyomartono (Kementerian Penerangan 1953: 117).

After the formation of SRV, the associations of Eastern radio stations grew like mushrooms in the rainy season. SRV formed branches in some cities in Java, Jakarta (1934), Bandung (1934), Surabaya (1934), Madiun (1934), and Semarang (1936). In Yogyakarta, it was based on the initiative of the nobility by cooperating with SRV established Mataramse Vereeniging voor Radio Omroep (MAVRO) in 1934. When encountering problems with NIROM broadcasting, in 1937 the Eastern radio associations joined together in the community of broadcasting agencies as Perikatan Perkumpulan Radio Ketimuran (PPRK, The Group of Eastern Radio Association) 
under the leadership of Sutarjo Kartohadikusumo (Kementerian Penerangan 1953: 14-15).

The submission of the Netherlands to Japan in March 1942 resulted in dramatic changes in the world of radio broadcasting. Wild (1987) that compared the broadcasting system under the Dutch government and the Japanese Military Administration and models providing the opportunity for the emergence of Indonesian radio, said that the model of broadcasting under the Japanese Military Administration conducted with strict censorship, government control, and entirely devoted to achieving national policy objectives and the condition of the public mind to accept and appreciate the national goals (Lindsay 1997: 110). Therefore, during the Japanese occupation of Indonesia (1942-1945), Military Government of Japan built a centralized broadcasting system. The entire broadcasting private radios were frozen and re-arranged by a special department called Hoso Kanri Kyoku which was a central radio station based in Jakarta with 15 branch stations (Hoso Kyoku), which had seven branches in Java, five branches in Sumatra, and one branch each in Makassar, Manado, and Banjarmasin. The entire staffs were the Indonesian people (Lindsay 1997: 110). Each Hoso Kyoku had some broadcasting stations and branch offices in each district (Shodanso). The office was tasked to unite all local radio repair shops or services, so all radio repairmen were directly under the supervision of the Japanese Military Administration. All radio was sealed, so that people could not listen to foreign broadcasts except Hoso Kyoku in Java (Kementerian Penerangan 1953: 12-14, 117).

Hoso Kyoku broadcasting mainly propaganda war program, was permitted in the Indonesian language. Indonesian music broadcasting was encouragely growing with Solo Hoso Kyoku broadcasts. Solo Hoso Kyoku broadcasts were always geared to the interests of the Japanese Military Administration. Therefore, the Indonesian staff of Solo Hoso Kyoku looked for the sidelines in terms of filling the nation struggle with the tendency of nationality. It was done by developing the arts and cultural broadcasts working with Keimin Bunka Shidoso a clever use of time, circumstances and place to achieve those goals. This opportunity gave birth to composers and singers of Indonesian songs (Kementerian Penerangan 1953: 12-14, 117). Beside Javanese art, famous broadcasts from Solo Hoso Kyoku were the broadcasts of Radio Orkes Surakarta (ROS, Surakarta Radio Orchestra) ${ }^{1}$ Indonesian song-singers, Kroncong, ${ }^{2}$ radio plays in the Indonesian language, ${ }^{3}$ Hawaiian Society of "Indonesia Muda" and Ksatria, ${ }^{4}$ and Indonesian songs (Kementerian Penerangan 1953: 12-14,

${ }^{1}$ Radio Orkes Surakarta (ROS) led by Sukarno (then Kamsidi) was a famous group orchestra not only in Surakarta, but also in Java.

2Among them were Lily Marie, Gesang, Mardjo Kahar, Annie Landouw, and Samsidi. Samsidi as talented young singers; They performed on the "Malam Percobaan" (Trial Night) held to provide an opportunity for young singers.

3The event was organized by the family of Indonesia Muda Surakarta. The stories that became famous plays were Arus Masa (The Flow), Tanah Tak Berdusta (Over Land Lying), and Sarung Pohung (Pohung Gloves) (Javanese).

4The singers in that event were Lilypali, Daldjono, and Sutantyo Singgih (Indonesia Muda) and Sunaryati. 
117). No wonder that during the Japanese occupation of the arts boomed.

When London BBC Radio and Radio of America announced the terms of surrender for Japan since 26 July 1945 until 11 August 1945 and then heard statements Tenno Heika to surrender to the Allies on 14 August 1945, the war in Asia would soon be stopped. But the Japanese Military Administration in Java was still going to cover the statement of Tenno Heika, even Kenpeitei of Surakarta strongly punished those who said that Japan had surrendered.

After the proclamation of the independence of Indonesia on 17 August 1945, on 18 August 1945 Maladi and Sutardi called by the head of the Japanese broadcast Yamamoto because of broadcasting Japan's defeat. On 19 August 1945 Jakarta Hoso Kanri Kyoku ordered to stop the broadcasts and waited for orders from the British occupation forces to come to Indonesia. The staff of the Radio planned a meeting to deal with uncertain conditions with respect to the defeat of Japan. Finally, on 11 September 1945 radio delegation from Jakarta, Bandung, Yogyakarta, Surakarta, Semarang, and Purwokerto held a conference in Jakarta that was opened by Dr. Abdul Rachman Saleh. The conference resulted in 13 decisions governing the establishment, staffing, and organizing RRI, as well as a determination of the steps that should be taken during the transition of power (Kementerian Penerangan 1953: 120-121).

After the conference 11 September 1945 in Jakarta, as the follow up of the decision of the conference, Solo Hoso Kyoku officials expressed a willingness and ability to work with the government and became the employee of the Republic of Indonesia. This statement was made under the banner of the Red and White in the yard of Kestalan Studio or in the street of Marconi, which was witnessed by the Japanese, Yasaki, and Yamamoto. On 1 October 1945, the Japanese Military Government handed over all power Solo Hoso Kyoku to Maladi. At the start of its formation, because there was no provision regulation and finance of the central government, thanks to Dr. Kartono, Surakarta Local Government (National Committee of Indonesia Region) was willing to lend funds to cover all the needs of RRI Surakarta that would be paid after receiving funds from the central government. Since 4 October 1945 RRI Surakarta organized broadcasts regularly. Then, on 1 April 1946 RRI was officially designated as Government agencies as the Bureau of Radio Republik Indonesia (Kementerian Penerangan 1953: 126-127), and Maladi was appointed as the head of the department. Since 1946 the central studio of RRI moved to Surakarta.

\section{Radio Republik Indonesia Surakarta, 1945-1950: Its Role in Efforts to Maintain Independence}

The proclamation of Indonesian independence on August 17, 1945 also blanketed radio broadcasting atmosphere. The nature of broadcasting turned into incendiary devices and drivers of struggle for independence. RRI that was formed through the conference 11 September 1945 at the early development should experienced the dynamics of history along with the wave of struggle for independence from the 
Dutch invasion troops who wanted to get its power back in Indonesia. After the conference, 11 September 1945 which founded the establishment of RRI, RRI Surakarta transmitter was active to broadcast with an independent Indonesia and based on the decision of the conference and the spirit of burning revolution (Djawatan Penerangan Propinsi Djawa Tengah 1953: 159). The first step taken was to implement the decision of 11 September 1945 by moving transmitters and search buildings in Tawangmangu as a transmitter and broadcast. It was done to anticipate that the transmitters could be spared from British or Dutch attacks. Finally, the transmitter and studio of RRI successfully established in Tawangmangu.

The position of the radio transmitter that was very strategic in the war became one of the objects of the British and the Netherlands espionage. They knew that through transmitters communication could be done and the outsourced the spirit of struggle of the Indonesian nation. Therefore, its existence should be eliminated. On 25 November 1945 British planes bombed and destroyed the Studio II of RRI Surakarta (Soepanto 1994: 51). They hit on target, but not as expected by the Dutch, because the transmitters had been moved before the bombing. After the bombing, the RRI Surakarta could still hold an emergency broadcast from a studio in Pasar Legi (former building of Keimin Bunka Shidoso) with the sound of "This is Radio Republik Indonesia Surakarta" (Djawatan Penerangan Propinsi Djawa Tengah 1953: 160).

To anticipate the circumstances that developed in the early days of independence, in 1947 a larger studio in Tawangmangu was used as Nusantara broadcast studios. The existence of English-language broadcasts in Tawangmangu, in addition to foreign broadcasts from Yogyakarta, and Nusantara broadcast alongside the national broadcast of Yogyakarta had raised questions among governments. However, as a matter of fact the broadcasts in English and Nusantara broadcast from Tawangmamngu by the exponents of RRI meant to keep everything that might happen. If anything happens to Yogyakarta, the broadcasts would be carried out through the studio and transmitter in Tawangmangu. In other words, the studio and transmitter in Tawangmangu could be a second front after Yogyakarta. This estimation did not miss because at Military Aggression II, when large transmitters in Yogyakarta did not work after the Yogyakarta occupied by the Dutch, then the transmitters in Tawangmangu continued the struggle to defend the independence of Indonesia (Djawatan Penerangan Propinsi Djawa Tengah 1953: 129).

During the Dutch Military Aggression II (Clash II, 1948), RRI Surakarta employees had the main role. At the time of the Dutch troops occupied the city of Surakarta, the entire staff under the leadership of Maladi left the town together with Tentara Nasional Indonesia (TNI, Indonesian National Army) and other fighters. Their departure brought transmitter that was strong enough to be caught by the receiver in Jakarta. RRI Surakarta on the run was headquartered in Balong a highland region in the district of Karanganyar. The transmitter used the term "the Guerilla of the Radio Republic of Indonesia" which broadcasted news about the activities of the national resistance against Dutch colony in Indonesia. With the role of guerrilla radio, the world became aware that Indonesia continued to struggle 
outside the cities, villages, and mountains to fight with a guerrilla war even though many major cities had fallen in the hands of the Dutch. The Guerrilla of the Radio Republic of Indonesia was always on the move because they escaped from the pursuit of the Dutch army, even constantly bombarded by using mitralijeur and bombed by planes that aimed to silence the broadcasts. The Guerrilla of the Radio Republic Indonesia broadcast news and commentaries in three languages, namely Indonesia, Dutch, and English (Pemerintah Daerah Kotamadya Surakarta 1974: 32). The broadcasts in English used the word called "Voice of Free of Republic of Indonesia" (Djawatan Penerangan Propinsi Djawa Tengah 1953: 161).

In this connection, it could not be forgotten the role of a leader information, Wim Latumeten who lived in Jakarta. He always made contact, and diligently broadcasted Balong guerrilla radio and forward news of Indonesian resistance against the Dutch in Surakarta by telling foreign journalists about Indonesian struggle to the world (Pemerintah Daerah Kotamadya Surakarta 1974: 32).

In addition to telephony broadcasts, it had been held the broadcast of the telegraphy code, called Republic of Indonesian Press (RIPRESS). According to Maladi, it aimed to be the voice of Indonesian nation that was more easily recognized by foreign parties such as Reuter and others (Ristutiningrum 1988: 94). The transmitter with its RIPRESS had been able to broadcast the guerrilla news from around Java and Sumatra. The transmitters could be managed well to establish relationships with private transmitters (amateur), among others in London, Berlin, Switzerland, and Sweden (Djawatan Penerangan Propinsi Djawa Tengah 1953: 161).

Towards the establishment of the Federal of the Republic of Indonesia, in August 1949 it was issued a ceasefire order in Surakarta. At that time among the leaders of RRI appeared the thought to dominate the broadcast in Indonesia. It was known that during the occupation, the Netherlands had established Radio Omroep in Overgangstijd (ROIO) in 1948 as a rival to RRI (Lindsay 1997: 110). Therefore, the leaders of RRI thought of the ways to take over ROIO, because the radio had to be in the hands of the Indonesian nation. In line with the discussions held between Indonesia and the Netherlands, with the permission of the Secretary-General of the Ministry of Information, Ruslan Abdulgani conducted informal talks between RRI with ROIO about the possibility to hold a fusion between the two would become one organization. According to Maladi (a head bureau and vice of RRI in the negotiations), the fusion between RRI with ROIO had to meet the conditions, namely in the form of a government department in the Federal Republic of Indonesia; led by Indonesian, ROIO should be dissolved; wealth, accounts payable, rights and obligations of RRI and ROIO should be taken over Radio Republik Indonesia Serikat (RRIS, The Radio of Federal Republic of Indonesia). If the principle of fusion between RRI and ROIO was not approved, up to 27 December 1949, it would still have two radio organizations in Indonesia. With its equipment would urge ROIO would harm RRI Broadcasts and would defeat the struggle of the Indonesian nation. Finally, on 27 December 1949, in conjunction with the "handover" of sovereignty RI was made a decree of the fusion between ROIO f and RRI to be Radio Republik Indonesia Serikat 
(RRIS) signed by Ruslan Abdulgani that it was suitable with the concept of Maladi (Kementerian Penerangan 1953: 110).

Maladi besides taking care handover in Surakarta, he also noticed redevelopment of the central office in accordance with the political development of the country with the establishment of the Federal Republic of Indonesia (RIS). The first steps were taken in compiling this department of technical and psychological angles. The studios were divided into the national studio (Jakarta), studios regional, sub-regional, local and relays. Central Bureau of Radio Republik Indonesia Serikat located in Jakarta had a large number of mixed employees (Indonesia and the Netherlands). The mutation and replacement of Dutch officials immediately made in accordance with the planned. All steps were directed to the national interest (Djawatan Penerangan Propinsi Djawa Tengah 1953: 162).

With the establishment of RRIS, then it turned RRI Surakarta into RRIS Surakarta. In December 1949, the head of RRIS Surakarta was handed to Sachlan Adisaputro. RRIS Surakarta was included in the regional studio (specializing in culture) (Djawatan Penerangan Propinsi Djawa Tengah 1953: 163). After Sukarno declared that the whole of Indonesia became a United States of Republic of Indonesia on 15 August 1950, then on 17 August 1950 RRIS changed its name to RRI (Effendy 1983; 62; Lindsay 1997:110).

\section{RRI Surakarta: the Efforts of Formation of National Culture, 1950-1960s}

As in most countries were experiencing decolonization, in Indonesia "nation-state is seen as a protective hedge of culture and cultural imperialism" (Betts 2004: 46; Bogaerts 2011: 256). Therefore, after the proclamation of independence on 17 August 1945, through the Cultural Congress was officially organized by the Indonesian government in Magelang in 1948 discussed the ways of defining culture in the context of post-colonial Indonesia (Supardi 2007: 132-155). Since the Congress in 1948 , this postcolonial context added a level of urgency and the need to take practical decisions related to cultural debates that had become part of the nationalist discourse since the 1930s (Bogaerts 2011: 256). For its realization, in the early 1950s, the Indonesian government would protect the freedom to effort culture, art, and science. On the basis of this principle, the Indonesian government would promote the development of nationalism in culture, arts, and sciences (Jones 2005: 95-96).

RRI was established with the aim to support government programs. Thus, since the establishment of RRI, it became the political and cultural media of the Indonesian government (Sen and Hill 2000: 82-84). Therefore, it was not possible to run political RRI broadcasts as opposed to government policy. RRI should participate in maintaining the safety of the country, by organizing broadcasts to maintain national unity (Kementerian Penerangan 1953: 252). As a consequence, RRI monopolized national news broadcasting, and its branches in the area gave some time to broadcast local events (Lindsay 1997: 111).

In its capacity as a government cultural media, RRI would make efforts towards collecting and broadcasting regional culture in order to be known by all the people of 
Indonesia. RRI would explore all the richness of the indigenous cultures of Indonesia to be introduced to the public. It was not meant to turn on the nature of regionalism, but it was the part of an effort to establish a national culture. Furthermore, regional cultures living in the community should be broadcast widely to all Indonesian people that rise independent assimilation process that could generate a new national culture. The spirit of the younger generation of artists to create works of art that had grown since the Japanese occupation should be maintained and released to the public. Therefore, the RRI channel had to be active to carry out these efforts (Kementerian Penerangan 1953: 253 \& 245).

In line with the policy that had been taken, RRI Surakarta organized broadcasts covering local arts, entertainments, and the National Music. In accordance with the culture, RRI Surakarta raised Javanese arts as a local art broadcasts. In the period 1950-1960s Javanese art broadcast of RRI Surakarta included karawitan (klenengan jangkep, gadhon, genderan, siteran, bonangan, langendriyan, santiswaran, etc.) wayang wong, kethoprak, and wayang kulit purwa which were lively broadcasted in the morning, afternoon, evening, and at night or in tape (LPs) (Mloyowibagso 1984: 66).

To organize the broadcast, in 1950 RRI Surakarta had to bring in artists from outside the RRI, because at that time RRI Surakarta did not have employees in the field of art. To hold a karawitan broadcast RRI Surakarta should bring pengrawit (Javanese musicians) that many of whom were from outside of the RRI, pengrawit from the Mangkunagaran and Kasunanan palaces. They were reliable pengrawit. An example was Sunarto Cipto Suwarso that since 1 March 1951 was accepted as an art worker (pengrawit) of RRI Surakarta. Previously, he became an abdi dalem langen praja (a palace servant of art) of Mangkunagaran in 1946-1950. He was accepted by RRI Surakarta as art worker because he had skills as a pretty good fiddle and bonang pengrawit, and was able to create and master the composition of gendhing (Darsono 2002: 115 \& 118). By that way, in 1950 RRI Surakarta had musical group, called Karawitan Studio RRI Surakarta under the direction of R. Ng. Harjosasmaya. In the development, the leadership position of the group was replaced by Panuju Atmosunarto (Mloyowibagso 1984: 66). Karawitan Studio RRI Surakarta was supported by several pesindhen (woman singers) namely Nyi Bei Pulangraras, Nyi Madyararas, Nyi Wara Podhang, Nyi Mandrarini, Nyi Larasmadu, Nyi Tambangraras, Nyi Wara Supami, Nyi Suyati, Nyi Sriyati, Nyi Sumarmi, and Nyi Tukinem.

RRI Surakarta karawitan musical broadcasts were also supported by the existence of groups of musicians from outside the RRI Surakarta. In the decade of 1950s, the karawitan musical groups that filled musical event broadcast included Karawitan Kraton Surakarta, Karawitan Mangkunagaran, Karawitan Prabuwinatan, Karawitan Muryararas Kusumayudan, Paguyuban Marsudi Raras, Paguyuban Mardi Wirama, ${ }^{5}$ as well as staff and students Conservatories of Karawitan Indonesia

5Pedoman Radio, No. 1-4 Djuni 1950; Pedoman Radio, No. 5 and 6 Djuli 1950; Berita Radio, No. 283 Tahun XIII, 29 Djuni-5 Djuli 1958, pp. 3-18; Berita Radio, No. 303 Tahun XIII, 16-22 Nopember 1958, pp. 3-19; Berita Radio, No. 304 Tahun XIII, 23-29 Nopember 1958, pp. 3-18; Berita 
Surakarta (Djawatan Penerangan Propinsi Jawa Tengah 1953: 453). Meanwhile, in the 1960s, several art associations had also been filled karawitan broadcast RRI Surakarta, including Sari Raras, Mardi Budaya, Perkumpulan Karawitan Kraton Surakarta, Harjaswara, Krida Raras, and Kumudawati (Mingguan Radio Republik Indonesia, 12 Mei 1963: 29-42).

Karawitan broadcast either live shows and recordings made by pengrawit (karawitan musicians) of RRI Surakarta had significance for its loyal fans, as a permanent document that would always be heard throughout the year. Suhardi (R. Anderson Sutton's teacher in Yogyakarta) testified that he was listening to the radio and focused on the recordings since the late 1950s-1960s. He could learn karawitan in depth, through several recordings of the same for many times. From the media that he could absorb the right patterns of karawitan. Suhardi also said that the recordings especially Lokananta had a great impact on the conception of himself and other musicians in the arrangement of gendhing that was delivered in sequence. ${ }^{6}$

To hold wayang wong broadcasts, RRI Surakarta also had to bring in the players from outside that made up the former wayang wong. They were the former Wayang Wong Sriwedari, artists who were inactive dancing because they were old or other reasons, but still wanted to preserve the art wayang wong via radio broadcast (Sutton 1991: 213-214). ${ }^{7}$ The broadcast held once a week on Tuesday night. The broadcast activities ran for a few years, so that the group as if it was a permanent member of the contract. They did not get paid, but only rudimentary transportation costs (Rusini 2003: 16; Moerwanto 1984: 64). ${ }^{8}$

At that time the players of wayang wong RRI Surakarta is had reliable sound quality, both for uttering dialogue (antawacana) and singing songs. They were also backed by a reliable pengrawit. Thus wayang wong broadcast was one event that endeared people, so many listeners wanted to see wayang wong performances RRI Surakarta. The leader of RRI Surakarta addressed public demand, and then in the early 1950s held a show with simple equipment. RRI had no clothes of wayang wong, screens, etc. for the purpose of performance as wayang wong RRI did not include performances, but for broadcasting purposes. Therefore, the performance was done by utilizing the front of the hall or space of RRI measuring approximately six feet five times without a screen. The audiences sat in chairs arranged on the lawn. Although the situation was very simple, the audiences were incredible. The audiences came from areas such as from Banyumas, Malang, and south (Surakarta

Radio, No. 305 Tahun XIII, 30 Nopember- 6 Desember 1958, pp. 3-18; Berita Radio, No. 306 Tahun XIII, 7-13 Desember 1958, pp. 3-18; Berita Radio, No. 319 Tahun XIII, 8-14 Maret 1959, p. 3-18.

${ }^{6}$ For example, he followed the gender game by Sabdosuwarno from RRI Surakarta, the conception of the gendhing (piece), cengkok (twisted), and wiledan as practiced by Sabdosuwarno.

7The players included Sastra Dirun (Petruk actor), Patra Wibaksa (Dasamuka, Druna, and sometimes Petruk actors), Priyana (Krishna actor), Sarwarini (Srikandi, Narayana, and Dewasrani actors), and Darmarini (Sumbadra actor) .

8There are 14 people, consisting of five female players, namely Sarworini, Harpiyah (Arjuna actor), Darmarini, Warni (Mustakaweni and Pergiwati actors), and Cepuk (emban and inang actors), nine men including Patra Wibaksa, Sastra Dirun, Priyana, Citra Yahman, Mlaya Darsana (Werkudara actor), Wida Darmana (Gathutkaca actor), and Jaya plus a leader. 
Rusini 2003: 17). Then in the mid-1950s, RRI built the theater and held a performance every Tuesday night, once a month. In addition, RRI also held a joint stage together with Perkumpulan Wayang Wong Sriwedari, thus adding to the splendor of performances, among others in welcoming the new year 1954 with Anoman Duta (Ambassador Anoman) story (Surakarta Rusini 2003: 17).

The broadcast and performance of wayang wong were one of the attractions for RRI Surakarta and became the amusement of the public. One fan (Tebyan) who at that time was a student SMP (Junior High School) Negeri 3 Surakarta testified that wayang wong broadcasts of RRI Surakarta became a favorite pastime for him. Wayang wong Broadcast of RRI Surakarta was able to captivate the hearts and brought the emotions of its audiences. In fact, he memorized the cast and puppet characters played. ${ }^{9}$ Because wayang wong broadcast became one attraction for RRI, then eventually proposed to be held the appointment of permanent employees for the players of wayang wong, pengrawit, and waranggana or pesindhen. In 1955 the proposals were received, and most of them became permanent employees of RRI Surakarta. Since 1955, RRI Surakarta had permanent employees (civil servants) as a player of wayang wong, pengrawit, and waranggana or sindhen (Rusini 2003: 18). ${ }^{10}$

Other local art broadcasts were organized by RRI Surakarta were kethoprak and wayang kulit purwa. Besides by Karawitan Studio RRI Surakarta, the kethoprak broadcast was hosted by Kelompok Kridomulyo and Kelompok Kesenian Jawa of RRI Yogyakarta. ${ }^{11}$ In the period 1950-1960 the dhalang ever broadcasted in RRI Surakarta including Ki Harjacarita (1950) (Pedoman Radio, 11 Djuni 1950: 20), Ki Wignyasutarna (Dewa Ruci, 1953) (Pandjangmas, 17 Nopember 1953: 19), Anonymous (Lahiripun Kakrasana, 1956) (Pandjangmas, 6 Maret 1956: 5), Ki Hagnyacarita (Dewa Amral, 1958) (Berita Radio, No. 306 Tahun XIII: 18), Ki Warsino (Ngruna-Ngruni, 1959) (Berita Radio, No. 319 Tahun XIII: 3-18), and (Anoman Trigangga, 1963) (Mingguan Radio Republik Indonesia, Tahun 2 No. 50: 42). The broadcast of the shadow puppet of RRI Surakarta was one of the program that received extensive attention from the public. It was partly evidenced by the reports and assessments Pandjangmas editor magazine. The editor on behalf of himself as Keprak reported that in November 1953 RRI Surakarta broadcasted shadow puppet play with Dewa Ruci by puppeteer Ki Wignyasutarna. He considered that it had demonstrated its ability through his teachings (Pandjangmas, 6 Maret 1956). In addition, the attention of the public was also shown by the criticism and demand, an explanation for the discrepancy in the story of Lahiripun Kakrasana in Saturday night performances on 21 January 1956 (Pandjangmas, 17 November 1953: 19).

9Tebyan, "Wayang Orang RRI Surakarta", Buletin Nglungsungi No. 32 April 2006. This bulletin was published by the alumni of SMP Negeri 3 Surakarta 1950-1960 with the homepage address at http://www.geocities.com/sinungra/smp3.htm.

${ }^{10}$ To increase the wage scale, they had to take a test which was held every two years for wayang wong player, every five years for pengrawit, and every three years for waranggana or sindhen. Gamelan and wayang wong broadcast on RRI Surakarta has been continuing up to now.

${ }^{11}$ Pedoman Radio, No. 211 Djuni 1950, p. 10; Pedoman Radio, No. 425 Djuni 1950, p. 10; Pedoman Radio, No. 69 Djuli 1950, p. 16; Berita Radio, No. 305 Tahun XIII 30 Nopember-6 Desember 1958, p. 3; Berita Radio, No. 319 Tahun XIII 8-14 Maret 1959. 
Other efforts by the government to establish a national culture quickly from regional materials supported by RRI were a type of music that became known as the "Hiburan Daerah" (Local Entertainment). In this case, RRI was a charge for broadcasting (later to publication and sale) a number of recordings of the kind of music that presents the songs of local language and culture of the region was derived from the standard tones and adapted to Western idioms and accompanied by a kind of orchestra. Hiburan Daerah seemed to have a strong presence in the recordings and broadcasts, rather than the actual shows, and without the support of RRI and promotion of music, it might fail its existence. A recording project to produce broadcasts was made, including the documentary recordings of the earliest music of the people in Kerinci, Angkola, Toba, Minang, Minahasa, Makassar, and Roti (Yampolsky 1995: 706-707). RRI Surakarta also made "Hiburan Daerah" to be one of the show broadcasts. Based on some issue numbers of Berita Radio in 1958 and 1959 it could be known about a program of RRI Surakarta which could be categorized into the "Hiburan Daerah", among them were Moluccas songs by Hatawano and Gema Saparua; Minahasa songs; Sasando Timor; Sumatra songs by Rayuan Perca; Malay songs by Pancaran Muda Group, Mercusuar Group, Sinar Agung Group, Barito Orchestra; Minang songs, Bukit Siguntang orchestra; Kulintang orchestra; and Balinese songs. ${ }^{12}$

National Music Broadcast (includes entertainment, original kroncong, new kroncong, kroncong outside the category of original and new, children's songs, seriosa, gambus, Malay music and songs of struggle) were the efforts taken by the RRI in shaping national culture. The broadcast on RRI Surakarta manifested in various names of broadcast events including Hiburan Siang [Afternoon Entertainment], Hiburan Petang (Evening Entertainment), Hiburan Malam (Night Entertainment), Irama Indonesia Indonesian Rhythm), Rayuan Pagi (Morning Flirt), Rayuan Siang (Afternoon Flirt), Rayuan Petang (Evening Flirt), Pengantar Makan Siang (Lunch Music), Sekedar Penawar Lelah (Just Charming Tired), Aneka Warna (Assorted Colors), Bisikan Malam (Night Whispers), Gema Malam (Night Echo), Malam Manasuka (Arbitrary Night), Keroncong Asli (Original Keroncong), and Hidangan Orkes Kenangan (Course Memories Orchestra). Besides Radio Orkes Surakarta (Surakarta Radio Orchestra) led by Kamsidi and then Dasuki, the events were filled by groups outside of the RRI Surakarta were majority from Orkes Keroncong (OK, keroncong orchestra) as OK Cepaka Putih, Tangkai Seruni, O.S.S., O.K. Sederhana, Orkes Kenangan, Gema Irama, Kuntum Seroja, OSD, Orkes Cendrawasih, OSB, Rayuan Indonesia Muda, OK Ksatria, Teruna Quartet, O.K. Puspa Kusuma, O.K. Panorama, O.K. Irama Muda, Suara Kencana, Orkes Nusantara, O.K. Pendawa, O.K. Setia, Kelana Jaya, Orkes Irama Baru, OKSJ, Suara Astana, OK Irama Sehat, O.R.S., O.R.J., Gema Dendang, O.K. Puspa Ragam, Orkes Mawar, O.K. Irama Massa, Orkes Garuda Putra, Puspa Harapan, and Puspa Teruna. ${ }^{13}$ From the various broadcasting events, it seemed that the National Music broadcasts were more than local art event 
broadcasts (Central Java), and Hiburan.

The implementation of RRI Surakarta in the mid 1950s-1960s was supported by the presence Lokananta founded in 1956 in Surakarta, since its founding related to efforts to shore up RRI in regions (Departemen Penerangan 1965: 120). ${ }^{14}$ Addition to perfecting discotheque of RRI and reducing foreign exchange, the establishment of Lokananta was intended to achieve the broader national ideal goals to increase the production of national LPs recordings, so the development of culture through LPs can be filled with national identity and foreign influences were not well be avoided (Departemen Penerangan 1965: 120). In carrying out its duties, Lokananta was based on basic guidelines, the struggle against imperialist musical influences on the lives of national music and folk music. The struggle was an essential part of the struggle to develop patriotism and strengthen the national identity in music (Departemen Penerangan 1965: 229-230). ${ }^{15}$ By relying on the basic guidelines that, during the period 1957-1971 had been producing recordings Lokananta LPs genre music of Central Java, Hiburan Daerah, and National Music (Yampolsky 1987: 10). ${ }^{16}$ National Music recording and music and theater in Central Java dominated the Lokananta production of records, which was about $7 / 8$ of the total production, the ratio of the number of National Music recording little more than a genre of music of Central Java (approximately 44\% and 41\% of total production (Yampolsky 1987: 14).

The efforts to establish a national culture was also achieved by the implementation of Lomba Bintang Radio (Radio Star Competition) since 1951. The competition for radio singers was divided into three categories such as vocal music, ie music series, musical entertainment, and keroncong music. The selection of radio star from the local, provincial and national became a fixed agenda broadcast of RRI stations, including RRI Surakarta (Hardjana 2003: 222-223). Unfortunately, until the completion of the writing of this article, the author does not get the information to provide an overview of the implementation of Radio Star Competition at RRI Surakarta. One for sure is Radio Star Competition organized by RRI Surakarta had given birth to the first winners in the National Radio Star Competition in 1951, Samsidi and Suprapti (Broadcasting Department of Ministry of Information of The

14The establishment of Lokananta was a realization of the idea proposed by the Director General of RRI in 1954. It has been known since 1952 RRI prepared for the construction of a five-year period as a whole in the program, engineering equipment, studio, and personnel with an outline of policy on prioritizing development local studios.

${ }^{15}$ The principal guidelines were translated into the five-point formula which was used as a reference in performing their duties. First, to develop patriotism in the music field needs to be done on the basis of the development of creative courage of total integration. Secondly, the music needs developing that could provide along with the fighting spirit of optimism to devour the music "kitsch" (West). Third, it should be developed by composing songs for children who would be executors and heir to the revolution. Fourth, as a coach's personality, then the product of recordings reflected the character of unity in diversity with emphasizing on music and folk songs. Fifth, the music was a branch of art that could be a medium of education and character building of the nation.

${ }^{16}$ The music genre of Central Java includes klenengan, music for weddings, dance accompaniment, dolanan, wayang kulit, wayang wong, kethoprak, and langgam Jawa; Regional Entertainment includes folk music of Malay, Karo, Simalungun, Tapanuli, Minang, South Sumatra, Kalimantan, Sulawesi, and the Moluccas; National music includes entertainment, kroncong original, new kroncong, kroncong beyond the original and a new category, children's songs, seriosa, gambus, Malayan music, fight song, and chant. 
Republik of Indonesia 1951). In addition, the Radio Star Competition organized by RRI Surakarta had also spawned the legendary singer in the keroncong, namely Waljinah who joined in The Radio Star Competition in Ex-Surakarta Residency since 1959 she became the first winner in the National Radio Star Competition for keroncong category in 1965 (Wijaya 2008: 86).

Radio Star Competition had spawned the first generation of Indonesian popular music. Except for the category of keroncong accompanied by a keroncong ensemble, at the initial selection of all singers accompanied by piano. Only in the final level, all the finalists either keroncong, entertainment, seriosa singers, accompanied by full orchestra consisting of 30-40 players. For the early development of music in Indonesia in 1950, a portrait of vocal music contest with symphony orchestra accompaniment was remarkable at that time. Each of the provincial capital had 2-3 studio orchestra or radio orchestra for keroncong, entertainment and serious music playing western classical music (Hardjana 2003: 224). RRI Surakarta since 1950 had studio orchestra or radio orchestra whose members came from Surakarta Radio Orchestra which was founded in 1943 and often filled in Solo Hoso Kyoku broadcasts. Based on the list of recording LPs of Lokananta period 1957-1971, RRI Surakarta had a studio orchestra or radio orchestra under the name of Orkes Studio Surakarta (Surakarta Studio Orchestra for seriosa), Orkes Keroncong Asli Studio Surakarta (Keroncong Surakarta Original Studio Orchestra for original keroncong and Langgam Jawa), and Radio Orkes Surakarta (Surakarta Radio Orchestra for new keroncong entertainment) (Yampolsky 1987: 14).

Radio Star Competition had also spawned the first generation of composers, songwriters, orchestrators, conductors, pianists and musical accompaniments. Names like Syaiful Bachri, Iskandar, Isbandi, Sutedjo, Subandi, E. Sambayon, and Samsidi were the orchestra leaders known at the time. While Harry Mulyono, Mochtar Embut, Sudharnoto were the pianists much preferred at the time (Hardjana 2003: 224). Samsidi and Sudharnoto were musical debutants from the Solo Hoso Kyoku during Indonesia's independence turned into RRI Surakarta.

Radio Star Competition 1950 was the period of the origin of the birth of popular songs, techniques, style of singing popular music in Indonesia. Except for keroncong, both in taste and style of the songs were presented in radio star competition took many lessons from popular music of the United States and Europe. However, the adaptation effect was successfully processed into its own distinctive style that was different from the original source (Hardjana 2003: 224).

In the annual reports of Radio Star Competition in RRI from 1951 onwards, Mimbar Indonesia showed a significant role of RRI in encouraging and promoting the searching of Indonesia music at that time (Bogaerts 2011: 275). On the other hand, from the point of Indonesian society in general radio star competition in the early 1950s became a vehicle for the Indonesian people to know the music more in general, direct, and open. The music was originally heard only in a limited circle, being able to be enjoyed by anyone, anytime and anywhere via the radio (Hardjana 2003: 223). 


\section{Conclusion}

Since its formation in 1945 until 1960, RRI Surakarta had two roles in the context of decolonization. In the period 1945-1950 RRI Surakarta had a role in the effort to maintain the independence of Indonesia. The RRI Surakarta employees struggled to maintain the existence of RRI Surakarta by rescuing the station and transmitter so that the struggle of the Indonesian nation in defending the independence of Indonesia could be broadcasted around the world. In the period 1950-1960s, RRI Surakarta participated in efforts to establish a national culture. When the discourse of national culture continued to be discussed by the elite of Indonesia, since 1950 the Bureau of Radio Republik Indonesia had set the establishment and the choice of ways to build a national culture. In this connection, RRI programs should be directed to establish a national culture. RRI Surakarta realized that idea by organizing Javanese art broadcasts, Hiburan Daerah, and the National Music and Radio Star Competition. RRI Surakarta through the Radio Star Competition had an important role in the creation of Indonesian popular music that was considered a form of national culture.

\section{References}

Berita Radio, No. 283 Tahun XII, 29 Djuni-5 Djuli 1958.

Berita Radio, No. 303 Tahun XIII, 16-22 Nopember 1958.

Berita Radio, No. 304 Tahun XIII, 23-29 Nopember 1958.

Berita Radio, No. 305 Tahun XIII, 30 Nopember-6 Desember 1958.

Berita Radio, No. 306 Tahun XIII, 7-13 Desember 1958.

Berita Radio, No. 319 Tahun XIII, 8-14 Maret 1959.

Bogaerts, Els (2011). "'Kemana Arah Kebudajaan Kita' Menggagas Kembali Kebudayaan di Indonesia pada Masa Dekolonisasi", in Jennifer Lindsay dan Maya H.T. Liem, eds., (2011). Ahli Waris Budaya Dunia: Menjadi Indonesia, 19501965. Denpasar - Jakarta: Pustaka Larasan dan KITLV.

Broadcasting Department of Ministry of Information of The Republik of Indonesia

(1951). Radio Republik Indonesia: Souvenir 1951. Djakarta: Broadcasting Department of Ministry of Information of The Republik of Indonesia.

Darsono (2011) Cokrodiharjo dan Sunarto Cipto Suwarso: Pengrawit-pengrawit Unggulan Luar Tembok Keraton. Surakarta: Citra Etnika.

Departemen Penerangan (1962). Kataloges Piring Hitam Lokananta. Surakarta: P.N. Lokananta.

Departemen Penerangan (1965). 20 Tahun Indonesia Merdeka Jilid IX: Departemen Penerangan. Jakarta: Departemen Penerangan.

Djawatan Penerangan Propinsi Djawa Tengah (1953). “Konservatori Karawitan Indonesia", in Republik Indonesia Propinsi Jawa Tengah. Semarang: Djawatan Penerangan Propinsi Djawa Tengah, 1953.

Djawatan Penerangan Propinsi Djawa Tengah (1953). “Pertumbuhan Penjiaran Radio di Surakarta", in Republik Indonesia Propinsi Jawa Tengah. Semarang: Djawatan Penerangan Propinsi Djawa Tengah. 
Effendi, Onong U. (1983). Radio Siaran Teori dan Praktek. Bandung: Alumni.

Hardjana, Suka (2003). Corat-coret Musik Kontemporer Dulu dan Kini. Jakarta: Ford Foundation dan Masyarakat Seni Pertunjukan Indonesia.

Jones, Tod (2005). Indonesian Cultural Policy, 1950-2003: Culture, Institutions, Government. Master Thesis. Curtin University of Technology Perth, (http://adt.curtin.edu.au/theses/available/adtWCU20061128.113236/unresticted/ downloaded on 5 September 2012).

Kementerian Penerangan (1953). Sejarah Radio di Indonesia. Djakarta: Djawatan Radio Republik Indonesia.

Lindsay, J. (1997). “Making Waves: Private Radio and Local Identities in Indonesia”. Indonesia 64 (1997).

Lindsay, J. (2011). "Ahli Waris Budaya Dunia 1950-1965; Sebuah Pengantar", in Lindsay J. dan Liem, Maya H.T. eds. (2011). Ahli Waris Budaya Dunia: Menjadi Indonesia, 1950-1965. Denpasar - Jakarta: Pustaka Larasan dan KITLV.

Mingguan Radio Republik Indonesia, Tahun 2 No. 5012 Mei 1963.

Mloyowibagso, Sardono (1984). "Karawitan R.R.I. Surakarta", in Hari Radio ke 39: 11

September 1984. Surakarta: Radio Republik Indonesia Stasiun Surakarta.

Moerwanto, Sri (1984). "Wayang Orang R.R.I. Surakarta", in Hari Radio ke 39: 11 September 1984. Surakarta: Radio Republik Indonesia Stasiun Surakarta.

Pandjangmas, Th. I No. 10, 17 Nopember 1953.

Pandjangmas, Th. IV No. 2, 6 Maret 1956.

Pedoman Radio, No. 1 - 4, Djuni 1950.

Pedoman Radio, No. 5 dan 6, Djuli 1950.

Pemerintah Daerah Kotamadya Surakarta. (1974). Buku Kenang-kenangan Perjuangan

Rakyat Surakarta dari Zaman ke Zaman. Surakarta: Pemerintah Daerah Kotamadya Surakarta.

Ristutiningrum, Margaretta Sri U. (1998). "Radio Republik Indonesia Surakarta pada

Periode Revolusi Fisik Tahun 1945-Tahun 1950 (Tinjauan tentang Peranan

Sosial Politiknya)". Undergraduate Thesis. Diponegoro University.

Rusini (2003). Gathutkaca di Panggung Soekarno. Surakarta: STSI Press.

Sen, Krishna dan Hill, David T. (2000) Media, Culture, and Politic in Indonesia. Oxford University Press.

Soepanto (1994). Hizbullah Surakarta. Karanganyar: Penerbit UMS.

Supardi, Nunus (2007). Kongres Kebudayaan (1918-2003), revised edition. Yogyakarta: Ombak.

Sutton, R. Anderson (1991). Traditions of Gamelan Music in Java: Musical Pluralism and Regional Identity. Cambridge: Cambridge University Press.

Tebyan (2006) "Wayang Orang RRI Surakarta". Buletin Nglungsungi No. 32 April 2006. Ppublished by the Alumni of SMP Negeri 3 (State Junior High School 3) Surakarta 1950-1960 in the website address: (http://www.geocities.com/ sinungra/smp3.htm).

Wijaya, Parenta (2008). “Kehidupan Musik Keroncong Langgam Jawa di Surakarta, 1959-1994". Undergraduate Thesis. Gadjah Mada University. 
Wild, Colin (1986). "Pengaruh Radio dalam Perjuangan", in Wild, Collin Ed., Gelora Api Revolusi. Jakarta: P.T. Gramedia.

Yampolsky, Philip (1995) "Forces for Change in Regional Performing Arts of Indonesia", Bijdragen Toot de Taal-, Land-en Volkenkunde, Deel 151, 4e Aflevering.

Yampolsky, Philip. 1987. Lokananta: A Discography of the National Recording Company of Indonesia 1957-1985. Bibliography Series, No. 10. Madison: University of Wisconsin, Center for Southeast Asian Studies. 